\title{
Resistance against phomopsis leaf blight disease induced by potassium salts in strawberry plants
}

\author{
Farid Abd-El-Kareem, Ibrahim E. Elshahawy and Mahfouz M. M. Abd-Elgawad*(1)
}

\begin{abstract}
Background: Growing interest of strawberry cultivation in Egypt necessitates more efforts towards its severe phomopsis leaf blight disease caused by Phomopsis obscurans. Synthetic fungicides could control this fungus but due to their critical impact on human beings and the environment, we are in dire need of safe alternatives for its control. Therefore, the leverage of the potassium bicarbonate and dipotassium phosphate on P. obscurans suppression on strawberry plants was examined.

Results: Full inhibition of the fungal linear growth was achieved at the highest concentration (2\%) of the two salts. Under field conditions, $87.5,81.3$, and $81.3 \%$ were the best decreases in disease severity gained by the two salts at $2 \%$ of both salts and the fungicide Amstar, respectively. Potassium bicarbonate at $1.5 \%$ reduced severity by $68.8 \%$. Concentrations $1,1.5$, and $2 \%$ of each salt considerably enhanced strawberry yield. The increases were 66.7 and $61.7 \%$, at $2 \%$ concentration by the two salts, respectively. Increments by 126.7 and $150 \%$ of peroxidase activity in plant leaves and by 140 and $148 \%$ of chitinase activity were noted by the two salts, respectively, at $2 \%$.

Conclusions: The examined bicarbonate and phosphate salts could suppress P. obscurans growth and spread. The more the used salt concentration, the better it suppresses the fungal growth with consequent effect on the plants which apparently promoted their field yield. Potential implications of the two salts on enhancing activities of the two enzymes reflected their role in suppressing the disease. Further research is needed to integrate these salts in management strategies of P. obscurans in Egypt to foster strawberry yield utilizing ecofriendly approaches.
\end{abstract}

Keywords: Enzyme activity, Potassium salts, Phomopsis obscurans, Strawberry yield

\section{Background}

Recently, strawberry (Fragaria $\times$ ananassa Duchesne) has accelerating importance in Egypt due to its economic and social benefits (Abd-Elgawad 2019). Yet, strawberry plants may be invaded by many pests and pathogens. They can cause significant yield and plant injury. In this vein, the fungus Phomopsis obscurans [(Ellis \& Everh.) B. Sutton] can frequently induce leaf blight disease in Egypt as a long-lasting with rapid-spread-fungal disease as few strawberry varieties have resistance to it (El-Shemy

*Correspondence: mahfouzian2000@yahoo.com

Plant Pathology Department, National Research Centre, Dokki, Egypt et al. 2013; Abd-El-Kareem et al. 2019a). The disease can severely attack leaves at different ages. Lesions appear as circular to elliptical, purple spots. They resemble those of leaf scorch or at least common leaf spots. These lesions develop and enlarge to affect general plant vigor. Infected leaves may also show specific shapes of lesions relative to the leaf edge (Elmer 1990; Louws 2007; Ellis and Nita 2008).

There has been renewable and considerable attention in utilizing sodium bicarbonate $\left(\mathrm{NaHCO}_{3}\right)$ and potassium bicarbonate $\left(\mathrm{KHCO}_{3}\right)$ for controlling various fungal diseases of plants (Karabulut et al. 2003; Smilanick et al. 2006). These bicarbonates are not only widely effective in the food industry (Lindsay 1985) but are also found to 
suppress plant diseases caused by several fungi. Spraying plants with $\mathrm{KHCO}_{3}$ solution offered the most efficient guard against such diseases (Fallik et al. 1996; Smilanick and Margosan 1999; Smilanick et al. 2006; Abd-ElKareem 2007). Bicarbonates efficient against powdery mildew has been apparent on various plant species; e.g. grape powdery mildew, Uncinula necator (Sawant and Sawant 2008). Bicarbonate salts offer good evidence as alternative options for suppressing such diseases, since they have fungicidal merits demonstrating a very low environmental and mammalian toxicity profile (Jamar et al. 2007).

Monopotassium phosphate $\left(\mathrm{KH}_{2} \mathrm{PO}_{4}\right)$ and dipotassium phosphate $\left(\mathrm{K}_{2} \mathrm{HPO}_{4}\right)$ are utilized as a food additive. The two salts have been approved as "safe" for use in our food by the U.S. Food and Drug Administration (Kuepper et al. 2001; Tamm et al. 2006). Potassium phosphates are also utilized as fertilizer. They constitute the main source of phosphorus for nutrition in agriculture. Moreover, applying them as a foliar spray could upgrade disease resistance in the attacked plants (Ignjatov et al. 2012) such as late blight disease on potato (Abd-El-Kareem et al. 2001), Alternaria leaf spot diseases on squash (Abd-El-Kareem et al. 2004), and powdery mildew on table grapes (Sawant and Sawant 2008).

The aim of this study is to evaluate the effect of potassium bicarbonate and potassium diphosphate against $P$. obscurans, the causal of phomopsis leaf blight of strawberry plants and its reflection on some pathogenesisrelated proteins and fruit yield.

\section{Methods}

\section{The pathogen isolate}

Pathogenic isolate of the above-mentioned Phomopsis obscurans was kindly offered by Phytopathology Department, National Research Centre (NRC), Egypt.

\section{Plant material}

Six-month-old seedlings of strawberry cv. Festival were bought from Ministry of Agriculture, Agricultural Research Centre, Giza, Egypt.

\section{Laboratory test}

Five concentrations of potassium bicarbonate $\left(\mathrm{KHCO}_{3}\right)$ and dipotassium phosphate $\left(\mathrm{K}_{2} \mathrm{HPO}_{4}\right)$, i.e. $0.0,0.5,1.0$, 1.5 , and $2.0 \%$ were utilized to study their effect on $P$. obscurans linear growth in the laboratory. The concentrations were added individually to sterilized potato dextrose agar (PDA) medium before solidification and then flowed in sterile Petri-plates. A fungal disc (6-mm) was inoculated in the center of each plate and plates were incubated at $25 \pm 1{ }^{\circ} \mathrm{C}$. Five plates served as replicates per a treatment including the untreated check plates. Seven days after incubation, linear growth was measured and the growth inhibition was assessed following Abd-ElKareem et al. (2019a).

\section{Field experiment}

A field experiment was carried out at El-Qalubia governorate, Egypt. The field was naturally infested with P. obscurans; as previously reported (Abd-El-Kareem et al. 2019a). This experiment was conducted in plots $(4 \times 8 \mathrm{~m})$ each comprised 8 rows ( 32 holes/row and one seedling was sown in each hole) in a randomized complete block design with three replicates (plots) for each treatment. On 20 November 2019, strawberry seedlings were planted in loamy clay well-drained soil to a depth of $10 \mathrm{~cm}$. All agricultural practices were done as recommended (El-Shemy et al. 2013).

\section{Treatments}

Similarly, the concentrations, i.e. $0.0,1.0,1.5$, and $2.0 \%$ of potassium bicarbonate and potassium phosphate were used to study their effect on leaf blight disease and yield of strawberry plants under field conditions during late fall, winter, and spring. All salt solutions were applied separately as foliar spray every 15 days to merely cover plant shoot system.

\section{Disease assessment}

Severity of Phomopsis leaf blight disease was assessed according to the scale offered by Louws (2007). Disease severity was recorded 100 days after transplanting.

\section{Determination of yield}

Accumulated yield of strawberry (Ton/feddan) in the experimental field was assessed at season-end on 30 April, 2020.

\section{Determination of enzyme activities}

Such activities in plant leaves (g), taken after 120 days of transplanting, were assessed based on extraction of enzymes indicated by Goldschmidt et al. (1968) for peroxidase (Abeles et al. 1971). For chitinase, the substrate was furnished from chitin powder (Ried and Ogryd-Ziak 1981). Assessing chitinase activity according to the procedure of Monreal and Reese (1969) and Abd-El-Kareem et al. (2019a) was followed.

\section{Statistical analysis}

Analysis of variance followed by Tukey test for multiple comparisons among means was utilized (Neler et al. 1985). 


\begin{tabular}{|c|c|c|c|}
\hline \multirow[t]{2}{*}{ Treatment } & \multirow{2}{*}{$\begin{array}{l}\text { Concentration } \\
\text { (\%) }\end{array}$} & \multicolumn{2}{|c|}{ Phomopsis obscurans } \\
\hline & & $\begin{array}{l}\text { Linear } \\
\text { growth } \\
(\mathrm{mm})\end{array}$ & Reduction (\%) \\
\hline Untreated control & 0.0 & $90.0 \mathrm{a}$ & 0.0 \\
\hline \multirow[t]{4}{*}{ Potassium bicarbonate } & 0.5 & $53.0 \mathrm{C}$ & 41.1 \\
\hline & 1.0 & $42.5 d$ & 52.8 \\
\hline & 1.5 & $20.1 e$ & 77.7 \\
\hline & 2.0 & $0.0 f$ & 100.0 \\
\hline \multirow[t]{4}{*}{ Potassium phosphate } & 0.5 & $74.0 \mathrm{~b}$ & 17.8 \\
\hline & 1.0 & $57.4 \mathrm{C}$ & 36.2 \\
\hline & 1.5 & $22.0 \mathrm{e}$ & 75.6 \\
\hline & 2.0 & $0.0 \mathrm{f}$ & 100.0 \\
\hline
\end{tabular}

Values with the same letter are not significantly different $(P \leq 0.05)$

Table 2 Effect of some chemical inducers on severity of Phomopsis leaf blight disease in strawberry plants under field conditions (120 days after planting)

\begin{tabular}{llll}
\hline Treatment & Concentration\% & \multicolumn{2}{l}{ Phomopsis leaf blight } \\
\cline { 3 - 4 } & & Disease severity & Reduction \\
\hline Untreated control & 0.0 & $1.6 \mathrm{a}$ & 0.0 \\
Potassium bi car- & 1.0 & $0.8 \mathrm{~b}$ & 50.0 \\
bonate & 1.5 & $0.5 \mathrm{c}$ & 68.8 \\
& 2.0 & $0.2 \mathrm{~d}$ & 87.5 \\
Potassium phos- & 1.0 & $0.9 \mathrm{~b}$ & 43.8 \\
phate & 1.5 & $0.7 \mathrm{~b}$ & 56.3 \\
& 2.0 & $0.3 \mathrm{~d}$ & 81.3 \\
Amstar (Fungicide) & $1 \mathrm{ml} / \mathrm{l}$ & $0.3 \mathrm{~d}$ & 81.3 \\
\hline
\end{tabular}

Values with the same letter are not significantly different $(P \leq 0.05)$

\section{Results}

\section{Effect on linear growth of $P$. obscurans}

Initially, the linear growth of $P$. obscurans was significantly reduced by the used concentrations of both salts (Table 1). Complete inhibition was obtained with both salt solutions at $2 \%$. At $1.5 \%$ concentration, the linear growth was reduced by 77.7 and $75.6 \%$ for potassium bicarbonate and potassium phosphate, respectively. The other concentrations showed moderate effect.

\section{Field experiment}

Results in Table 2 show that all tested concentrations considerably decreased the disease severity (Fig. 1). The highest reduction of disease severity was obtained with both salts at concentration of $2 \%$ compared to the fungicide. Moderate reduction was obtained with potassium bicarbonate at $1.5 \%$ which reduced the disease severity by $68.8 \%$. Other concentrations were less effective.

\section{Effect on strawberry yield}

The applied concentrations of salts could remarkably enhance strawberry yield (Table 3; Fig. 2). The highest increase was obtained with potassium bicarbonate and dipotassium phosphate at concentration of $2 \%$ which increased the strawberry yield by 66.7 and $61.7 \%$, respectively. Moderate increase was obtained with potassium bicarbonate and dipotassium phosphate at $1.5 \%$ which increased the strawberry yield by 40.0 and $36.7 \%$, respectively. Other treatments were less effective.

\section{Effect on enzyme activities}

Results in Table 4 demonstrate that all tested treatments significantly increased the enzyme activities. The highest increase was obtained with potassium bicarbonate and dipotassium phosphate at concentration of $2 \%$ which increased the peroxidase activity by 126.7 and $150 \%$ as well as chitinase activity by 140 and $148 \%$, respectively. Such activities were directly proportional to the salt concentrations. So, moderate increase was obtained with potassium bicarbonate and dipotassium phosphate at $1.5 \%$.

\section{Discussion}

Plant diseases caused by soil-borne pathogens are considered major problems in strawberry production in Egypt as they considerably reduce yield and fruit quality (ElShemy et al. 2013; Abd-El-Kareem et al. 2019a; Abd-Elgawad 2019). Among them, control of phomopsis leaf blight disease could be tried via using hazardous fungicides which are toxic to human beings and animals and cause environmental pollution (El-Shemy et al. 2013; Rashad and Moussa 2020). Fortunately, complete inhibition in linear growth of $P$. obscurans was obtained herein with two safe salts: potassium bicarbonate and dipotassium phosphate at $2 \%$. Hence, a more balanced, cost effective and eco-friendly methods were adopted herein under field conditions. In this respect, potassium bicarbonate has widespread use in crops. Notably, it can be used as an effective fungicide against scab and sooty blotch on apples (Tamm et al. 2006), powdery mildew on several economically important crops (Kuepper et al. 2001; Crisp et al. 2006; Sawant and Sawant 2008) and other root rot and wilt diseases (Abdel-Monaim et al. 2015). Contrary to other hazardous fungicides, its relevant utilization is so safe that it is allowed for use in organic farming (Kuepper et al. 2001). Therefore, it is timely to further examine its efficacy on other important diseases such as the 


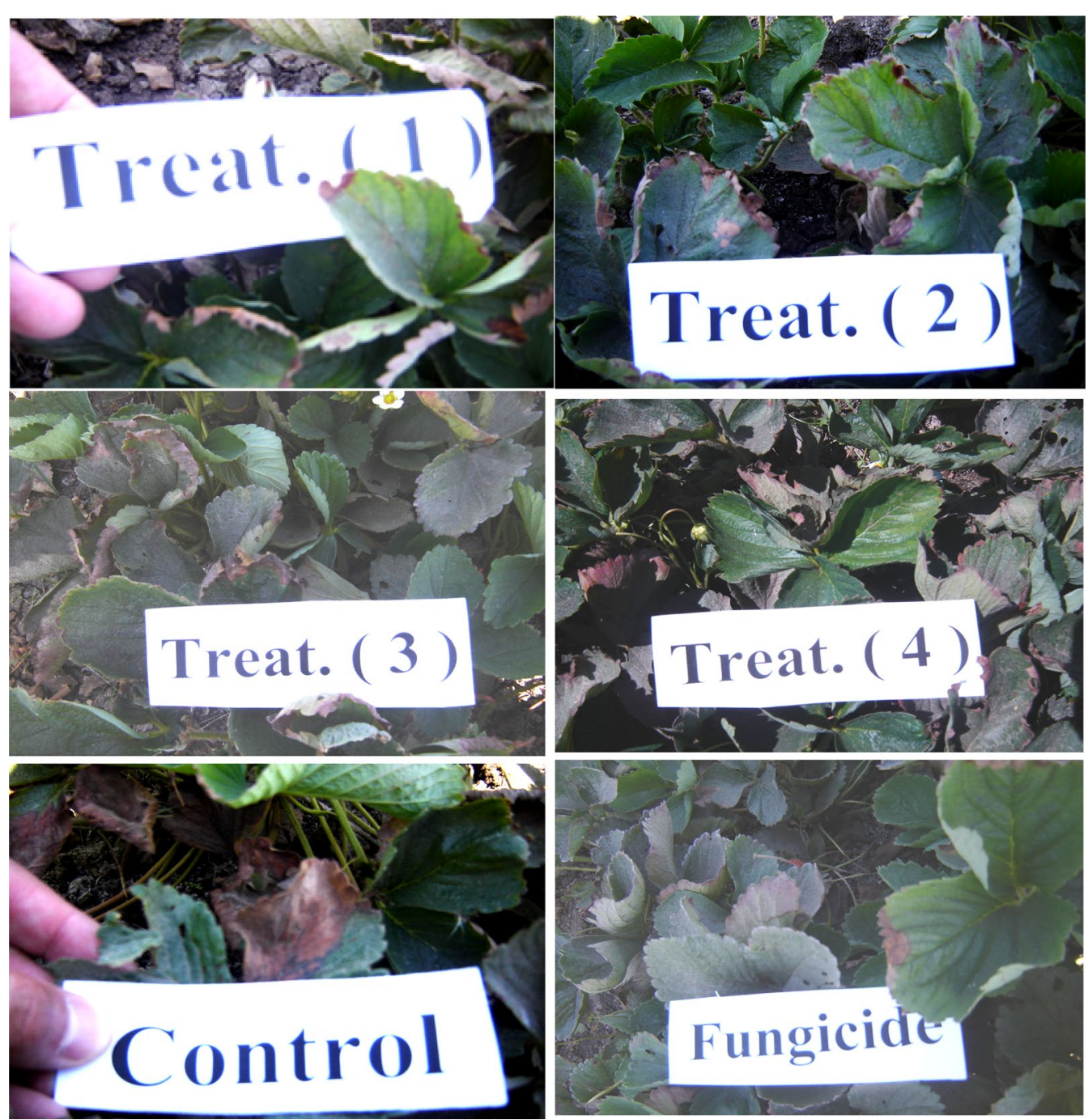

Fig. 1 Lesion symptoms caused by phomopsis leaf blight disease under field conditions in different treatments; 1: Potassium bicarbonate at 1.5\%, 2: Potassium bicarbonate at 2.0\%, 3: diPotassium phosphate at 1.5\%, 4: diPotassium phosphate at 2.0\%; in addition to the fungicide (Amstar at $1 \mathrm{ml} / \mathrm{l})$ and the untreated control

above-mentioned apple diseases in Egypt. That is because management of scab-susceptible cultivars and sooty blotch in scab-resistant cultivars is often difficult and not sufficiently successful (Tamm et al. 2006). Additionally, as an inexpensive, nontoxic base, it is widely used in diverse application to regulate $\mathrm{pH}$ or as a reagent. Ammonium bicarbonate had the strongest effect on some diseases, but potassium and sodium bicarbonates worked best against others. For example, potassium bicarbonate provided the best control of powdery mildew. Sodium bicarbonate is okay, but it is not as good (Kuepper et al. 2001). Likewise, potassium phosphates proved to be effective against phytopathogenic fungi (Arslan 2015; El-Fawy and El-Said 2018). Yet, until recently, such safe salts have not been reported as management solutions for several apple diseases in Egypt (Youssef and Roberto 2020).

The inhibitory mechanisms of bicarbonates were explained in terms of hydrogen ion concentration effect of the salts which demonstrated a profound inhibitory effect on sclerotia and conidia germination of Sclerotium rolfesii and S. fuliginea, respectively (Punja and Grogan 1982; Homma et al. 1981). Furthermore, filmforming polymers may form a physical barrier on leaf surfaces against germ tube penetrations (Elad et al. 1989; Ziv and Zitter 1992). In addition, potassium bicarbonate can cause the collapse of hyphal walls and shrinkage of conidia (Punja and Grogan 1982; Ziv and Zitter 1992). Jamar et al. (2007) speculated that $\mathrm{KHCO}_{3}$ acts 
Table 3 Effect of some chemical inducers on strawberry yield under field conditions

\begin{tabular}{|c|c|c|c|}
\hline \multirow[t]{2}{*}{ Treatment } & \multirow{2}{*}{$\begin{array}{l}\text { Concentration } \\
\text { (\%) }\end{array}$} & \multicolumn{2}{|c|}{ Strawberry yield } \\
\hline & & $\begin{array}{l}\text { Yield } \\
\text { (tons/ } \\
\text { feddan) }\end{array}$ & Increase \% \\
\hline Untreated control & 0.0 & $6.0 d$ & 0.0 \\
\hline \multirow[t]{3}{*}{ Potassium bi carbonate } & 1.0 & $7.7 c$ & 28.3 \\
\hline & 1.5 & $8.4 b$ & 40.0 \\
\hline & 2.0 & $10.0 \mathrm{a}$ & 66.7 \\
\hline \multirow[t]{3}{*}{ Potassium phosphate } & 1.0 & $7.5 c$ & 25.0 \\
\hline & 1.5 & $8.2 b c$ & 36.7 \\
\hline & 2.0 & 9.7 a & 61.7 \\
\hline Amstar (fungicide) & $1 \mathrm{ml} / \mathrm{l}$ & $8.0 \mathrm{bc}$ & 33.3 \\
\hline
\end{tabular}

Values with the same letter(s) are not significantly different $(P \leq 0.05)$

as a contact fungicide and is not likely to be systemic or curative. Interestingly, in this study, $\mathrm{KHCO}_{3}$ and $\mathrm{K}_{2} \mathrm{HPO}_{4}$ at $2 \%$ concentration in addition to the fungicide Amstar could reduce the disease severity as high as $87.5,81.3$ and $81.3 \%$, respectively, under field conditions. Consequently, $\mathrm{KHCO}_{3}$ and $\mathrm{K}_{2} \mathrm{HPO}_{4}$ at $2 \%$ concentration could increase the yield by 66.7 and $61.7 \%$, respectively.

The most increase in enzyme activities for both salts was also obtained at $2 \%$ concentration. In this regards, a few investigations reported the use of potassium salts as a chemical agent for induction of plant resistance (Ignjatov et al. 2012; Abdel-Monaim et al. 2015). For example, mono and dipotassium phosphates have shown efficacy against several plant diseases via induced systemic resistance (ISR) (Uppal et al. 2007; Amini and Sidovich 2010; Abd-El-Kareem et al. 2010; Abdel-Monaim et al. 2015). In these and other studies, resistance inducers can cause differential changes in both the activity and the banding intensity of the defensive enzymes such as peroxidase and chitinase, reported herein, found in the protein extracts of plant leaves. Such high activity levels of pathogenesisrelated proteins are associated with greater disease resistance, and therefore may be utilized as useful biochemical markers of ISR (Oostendorp et al. 2001; Buzi et al. 2004; Abd-Elgawad and Kabeil 2012; Abd-Elgawad et al. 2012; Abd-El-Kareem et al. 2019b). These salts can offer systemic acquired resistance to numerous plant pathogens (Reuveni and Reuveni 1998; Abd-El-Kareem et al. 2001, 2004; Abdel-Monaim et al. 2015).

\section{Conclusion}

In Egypt, strawberry cultivation and yield has elevated significance due to its increased social and economic gains in recent years. However, expanding its cultivation areas is frequently associated with considerable yield losses due to attack by numerous pests and diseases. The serious leaf blight disease of strawberry, caused by the fungus Phomopsis obscurans, requires proper and safe management strategy in every respect as a worthy follow-up to remarkably enhance crop yield. The results obtained herein demonstrated that all concentrations of potassium bicarbonate and dipotassium phosphate could

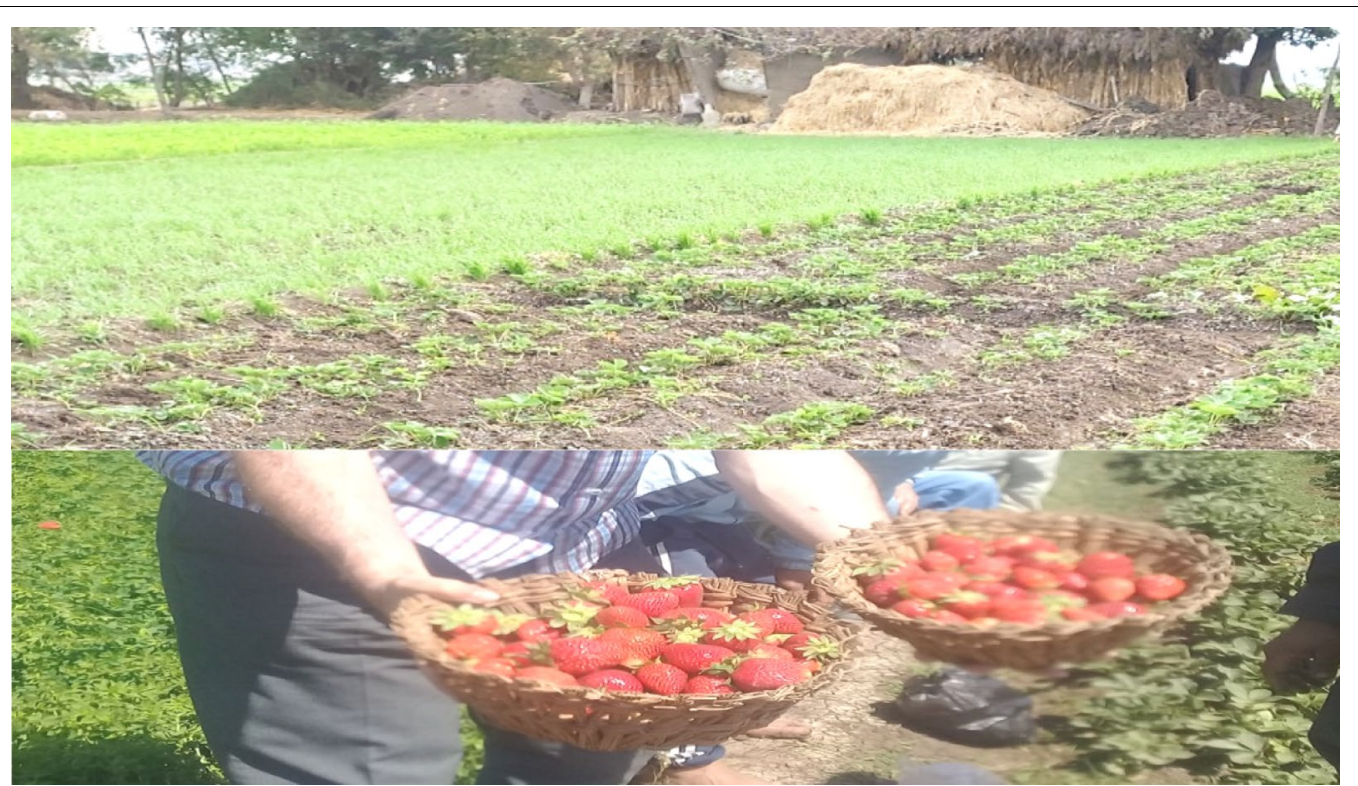

Fig. 2 Upper: strawberry with the treatments (upper left) adjacent to (right) the untreated check. Lower: more strawberry yield fruits from salt-treated (left) than untreated plots 
Table 4 Effect of two potassium salts at different concentrations and a fungicide on enzyme activities in strawberry leaves grown under field conditions

\begin{tabular}{|c|c|c|c|c|c|}
\hline \multirow{3}{*}{$\begin{array}{l}\text { Treatment } \\
\text { Potassium bicarbonate }\end{array}$} & \multirow{3}{*}{$\begin{array}{l}\text { Concentration (\%) } \\
-\end{array}$} & \multicolumn{4}{|c|}{ Enzyme activities } \\
\hline & & \multicolumn{2}{|c|}{ Peroxidase } & \multicolumn{2}{|c|}{ Chitinase } \\
\hline & & Activity & Increase \% & Activity & Increase \% \\
\hline & 1.0 & $15.4 \mathrm{C}$ & 71.1 & $4.5 \mathrm{~d}$ & 76.0 \\
\hline & 1.5 & $18.5 b$ & 105.6 & $5.8 b$ & 132.0 \\
\hline & 2.0 & $20.4 a$ & 126.7 & $6.0 \mathrm{a}$ & 140.0 \\
\hline \multirow[t]{3}{*}{ Potassium phosphate } & 1.0 & $16.0 \mathrm{c}$ & 77.8 & $5.0 \mathrm{c}$ & 50.0 \\
\hline & 1.5 & $19.2 b$ & 113.3 & $5.5 b$ & 120.0 \\
\hline & 2.0 & $22.5 \mathrm{a}$ & 150.0 & $6.2 \mathrm{a}$ & 148.0 \\
\hline Amstar (fungicide) & $1 \mathrm{ml} / \mathrm{l}$ & $15.0 \mathrm{C}$ & 66.7 & $5.0 \mathrm{c}$ & 50.0 \\
\hline Untreated control & - & $9.0 \mathrm{~d}$ & 0.0 & $2.5 d$ & 0.0 \\
\hline
\end{tabular}

Values with the same letter are not significantly different $(P \leq 0.05)$

significantly decrease this disease under laboratory and field conditions. Such a remarkable decrease in the disease severity has resulted in unmistakably strawberry yield increase which was positively correlated with the added salt concentration. This increase has also a progressive correlation with activities of both peroxidase and chitinase. Large scale studies are warranted to integrate these salts in the management strategy of strawberry diseases in Egypt to improve the disease-control efficacy and crop yield while providing more economically and environmentally acceptable approach.

\section{Abbreviations}

ISR: Induced systemic resistance; PDA: Potato dextrose agar.

\section{Acknowledgements}

This study was supported in part by the US-Egypt Project cycle 17 (No. 172) entitled 'Preparing and evaluating IPM tactics for increasing strawberry and citrus production'. This article is derived from the Subject Data funded in part by NAS and USAID, and that any opinions, findings, conclusions, or recommendations expressed in it are those of the authors alone, and do not necessarily reflect the views of USAID or NAS. Facilities offered by The National Research Centre are appreciated.

\section{Authors' contributions}

FA analyzed and interpreted the data statistically. All authors performed the field visits to follow the experimentation and record data, and both FA and MA were major contributors in writing the manuscript. All authors read and approved the final manuscript.

\section{Funding}

Financial support was partially made by both US-Egypt Project related to Science and Technology Development Fund via Project cycle 17 (No. 172) and National Research Centre, Egypt.

\section{Availability of data and materials}

The datasets used and/or analyzed during the current study are available from the corresponding author on reasonable request.

Ethics approval and consent to participate Not applicable.

\section{Consent for publication}

Not applicable.

\section{Competing interests}

The authors declare that they have no competing interests.

Received: 30 July 2020 Accepted: 13 September 2020

Published online: 24 September 2020

\section{References}

Abd-Elgawad MMM (2019) Plant-parasitic nematodes of strawberry in Egypt: a review. Bull NRC 43:7. https://doi.org/10.1186/s42269-019-0049-2

Abd-Elgawad MMM, Kabeil SSA (2012) Biological control of Meloidogyne incognita by Trichoderma harzianum and Serratia marcescens and their related enzymatic changes in tomato roots. Afr J Biotechnol 11:16247-16252

Abd-Elgawad MMM, Kabeil SSA, Fanelli E, Molinari S (2012) Different levels of anti-oxidant enzyme activities in tomato genotypes susceptible and resistant to root-knot nematodes. Nematropica 42:328-334

Abd-El-Kareem F (2007) Potassium or sodium bicarbonates in combination with Nerol for controlling early blight disease of potato plants under laboratory, greenhouse and field conditions. Egypt J Phytopathol 35:73-86

Abd-El-Kareem F, Abd-Alla MA, El-Mohamedy RSR (2001) Induced resistance in potato plants for controlling late blight disease under field conditions. Egypt J Phytopathol 29(2):29-41

Abd-El-Kareem F, El-Mougy NS, El-Gamal NG, Fotouh YO (2004) Induction of resistance in squash plants against powdery mildew and Alternaria leaf spot diseases using chemical inducers as protective or therapeutic treatments. Egypt J Phytopathol 32(1-2):65-76

Abd-El-Kareem F, Abd-El-Latif FM, Fotouh YO (2010) Induction of resistance against Cercospora leaf spot disease of sugar beet plants under field conditions. Egypt J Phytopathol 38:173-183

Abd-El-Kareem F, Elshahawy IE, Abd-Elgawad MMM (2019a) Management of strawberry leaf blight disease caused by Phomopsis obscurans using silicate salts under field conditions. Bull NRC 43:1. https://doi.org/10.1186/ s42269-018-0041-2

Abd-El-Kareem F, Elshahawy IE, Abd-Elgawad MMM (2019b) Effectiveness of silicon and silicate salts for controlling black root rot and induced pathogenesis-related protein of strawberry plants. Bull NRC 43:91. https:// doi.org/10.1186/s42269-019-0139-1

Abdel-Monaim MF, Atwa MAM, Morsy KM (2015) Induce systemic resistance against root rot and wilt diseases in fodder beet (Beta vulgaris L. var. rapacea Koch) by using potassium salts. J Plant Pathol Microbiol 6:315. https:// doi.org/10.4172/2157-7471.1000315 
Abeles FB, Bosshart RP, Forrence LE, Habig WH (1971) Preparation and purification of glucanase and chitinase from bean leaves. Plant Physiol 47:129-134

Amini J, Sidovich DF (2010) The effect of fungicides on Fusarium oxysporum sp. lycopersici associated with Fusarium wilt tomato. J Plant Prot Res 50:172-178

Arslan U (2015) Evaluation of antifungal activity of mono and dipotassium phosphates against phytopathogenic fungi. Fresenius Environ Bull 24(3):810-816

Buzi A, Chilosi G, Magro P (2004) Induction of resistance in melon seedlings against soil-borne fungal pathogens by gaseous treatments with methyl jasmonate and ethylene. J Phytopathol 152:491-497

Crisp P, Wicks TJ, Bruer D, Scott ES (2006) An evaluation of biological and abiotic controls for grapevine powdery mildew. 2. Vineyard trials. Austr J Grape Wine Res 12:203-211

Elad Y, Zive O, Ayash N, Katan J (1989) The effect of film forming polymers on powdery mildew of cucumber. Phytoparasitica 17:179-288

El-Fawy MM, El-Said MAA (2018) Effect of foliar application of some zinc and phosphorus sources on controlling Helminthosporium leaf spot disease and production of sesame. J Plant Prot Path Mansoura Univ 9(3):201-207

Ellis MA, Nita M (2008) Phomopsis leaf blight and fruit rot of strawberry. Agric Nat Resour (On Line)

Elmer WH (1990) Recent outbreak of Phomopsis leaf blight, caused by Phomopsis obscurans, on strawberry petioles and stolons in Connecticut. Plant Dis 74:331-334

El-Shemy AA, Khafagy YS, Al-Genteery AMM (2013) Cultivation and production of strawberry. Cairo: Tech issue no. 9/2013, General Directorate of Agricultural Culture. Egyptian Ministry of Agriculture (in Arabic)

Fallik E, Grinberg S, Ziv O (1996) Potassium bicarbonate reduces postharvest decay development on bell pepper fruits. J Hortic Sci 71:121-127

Goldschmidt EE, Goren R, Monselise SP (1968) The indol acetic acid oxidase system of citrus roots. Planta 72:213-222

Homma Y, Arimoto Y, Misato T (1981) Studies on the control of plant diseases by sodium bicarbonate formulation. 2 . Effect of sodium bicarbonate on each growth stage of cucumber powdery mildew fungus (Sphaerotheca fuliginea) in its life cycle. J Pest Sci 6:201-209

Ignjatov M, Miloševi D, Nikoli Z, Gvozdanovi J, Jovi D (2012) Fusarium oxysporum sp. lycopersici as causal agent of tomato wilt and fruit rot. Pest Phytomed 27:25-31

Jamar L, Lefrancq B, Lateur M (2007) Control of apple scab (Venturia inequalis) with bicarbonate salts under controlled environment. J Plant Dis Prot 114(5):221-227

Karabulut OA, Bursa G, Mansour M (2003) Near-harvest applications of metschnikowia fructicola, ethanol, and sodium bicarbonate to control postharvest diseases of grape in Central California. Plant Dis 87:1384-1389

Kuepper G, Thomas R, Earles R (2001) Use of baking soda as a fungicide. National Center for Appropriate Technology. https://attra.ncat.org/attra -pub/viewhtml.php?id=126. Accessed 8 June 2020

Lindsay RC (1985) Food additives. Chapter 10. In: Fennema OR (ed) Food chemistry. Marcel Dekker, Inc., New York
Louws JF (2007)Detection and management of anthracnose and Phomopsis blight in strawberry production in the Southeast. Progress Report Grant Code: SRSFC, 2007-05

Monreal J, Reese ET (1969) The chitinase of Serratia marcescens. Can J Microbiol 15:689-696

Neler J, Wassermann W, Kutner MH (1985) Applied linear statistical models. Regression, analysis of variance and experimental design, 2nd edn. Richard D. Irwin Inc., Homewood

Oostendorp M, Kunz W, Dietrich B, Staub T (2001) Induced disease resistance in plants by chemicals. Eur J Plant Pathol 107:19-28

Punja Z, Grogan RG (1982) Effects of inorganic salts carbonate-bicarbonate anions, ammonia, and the modifying influence of $\mathrm{pH}$ on sclerotia germination of Sclerotium rolfsii. Phytopathology 72:635-639

Rashad YM, Moussa TAA (2020) Biocontrol agents for fungal plant diseases management. In: El-Wakeil N, Saleh M, Abu-hashim M (eds) Cottage industry of biocontrol agents and their applications. Springer, Cham, pp 337-363

Reuveni R, Reuveni M (1998) Foliar fertilizer therapy—a concept in integrated pest management. Crop Prot 17:111-118

Ried JD, Ogryd-Ziak DM (1981) Chitinase over producing mutant of Servatia marcescens. Appl Environ Microbiol 41:664-669

Sawant SSD, Sawant IS (2008) Use of potassium bi-carbonates for the control of powdery mildew in table grapes. Acta Hortic 785:285-292. https://doi. org/10.17660/ActaHortic.2008.785.34

Smilanick JL, Margosan DA (1999) Control of citrus green mold by carbonate and bicarbonate salts and the influence of commercial postharvest practices on their efficacy. Plant Dis 83:139-145

Smilanick JL, Mansour MF, Sorenson D (2006) Pre- and postharvest treatments to control green mold of citrus fruit during ethylene degreening. Plant Dis 90:89-96

Tamm L, Amsler T, Schärer H, Refardt M (2006) Efficacy of Armicarb (potassium bicarbonate) against scab and sooty blotch on apples. In: Boos M (ed) Proceedings 12th international conference on cultivation technique and phytopathological problems in organic fruit growing. FÖKO, Weinsberg, pp 87-92

Uppal AK, Hadrami A, Adam LR, Tenuta M, Daayf F (2007) Pathogenic variability of Verticillium dahliae isolates from potato fields in Manitoba and screening of bacteria for their biocontrol. Can J Plant Pathol 29:141-152

Youssef K, Roberto SR (2020) Premature apple fruit drop: associated fungal species and attempted management solutions. Horticulturae 6:31. https ://doi.org/10.3390/horticulturae6020031

Ziv O, Zitter TA (1992) Effects of bicarbonates and film-forming polymers on cucurbit foliar diseases. Plant Dis 76:513-517

\section{Publisher's Note}

Springer Nature remains neutral with regard to jurisdictional claims in published maps and institutional affiliations.

\section{Submit your manuscript to a SpringerOpen ${ }^{\circ}$ journal and benefit from:}

- Convenient online submission

- Rigorous peer review

- Open access: articles freely available online

- High visibility within the field

- Retaining the copyright to your article

Submit your next manuscript at springeropen.com 